\title{
Mite fauna (Acari) associated to commercial laying hens and bird nests in Vale do Taquari, Rio Grande do Sul, Brazil
}

\author{
Guilherme Liberato da Silva ${ }^{1 *}$ \\ Noeli Juarez Ferla ${ }^{2}$ \\ Maicon Toldi ${ }^{2}$ \\ Daiâni Cristina Cardoso Faleiro ${ }^{2}$ \\ ${ }^{1}$ Universidade Federal de Pelotas \\ Avenida Eliseu Maciel, s/n, Campus Capão do Leão, CEP 96001-970, Pelotas - RS, Brasil \\ ${ }^{2}$ Centro Universitário UNIVATES \\ Avenida Avelino Tallini, s/n, Campus Capão do Leão, CEP 95900-000, Lajeado - RS, Brasil \\ * Autor para correspondência \\ gibaliberato_148@hotmail.com
}

Submetido em $11 / 04 / 2013$

Aceito para publicação 20/08/2013

\section{Resumo}

Acarofauna (Acari) associada a poedeiras comerciais e ninhos de pássaros no Vale do Taquari, Rio Grande do Sul, Brasil. O controle de ectoparasitos é fundamental para a manutenção da biossegurança de uma granja avícola. Este artigo teve por objetivo analisar a acarofauna associada a ninhos abandonados e poedeiras comerciais nos municípios de Lajeado e Teutônia, Vale do Taquari, Rio Grande do Sul. As amostragens foram realizadas de dezembro de 2010 a julho de 2011. Um total de 11.757 ácaros pertencentes a 21 famílias e 31 espécies foi encontrado. Cheyletidae mostrou maior número de espécies (4), seguida de Blattisocidae (3 espécies). Dermanyssus gallinae (De Geer) apresentou maior número de indivíduos (5.689), seguida de Megninia gynglimura Mégnin (2.175) e Chortoglyphus arcuatus Troupeau (1.488). Blattisocius tarsalis Berlese, C. arcuatus e D. gallinae foram encontrados em armadilhas, em penas, ninhos de granja sem gaiolas (livres) e em ninhos de pássaros abandonados.

Palavras-chave: Acariose; Avicultura; Dermanyssus gallinae; Ectoparasita; Megninia ginglymura

\section{Abstract}

The control of ectoparasites is essential for maintaining biosafety in a poultry farm. This paper aimed to analyze the mite fauna associated to abandoned nests and commercial laying hens in the towns of Lajeado and Teutônia, Vale do Taquari, Rio Grande do Sul, Brazil. Samplings were conducted from December 2010 to July 2011. A total of 11,757 mites belonging to 21 families and 31 species were found. Cheyletidae showed the highest number of species (4), followed by Blattisocidae (3 species). Dermanyssus gallinae (De Geer) showed the highest number of individuals (5,689), followed by Megninia gynglimura Mégnin $(2,175)$, and Chortoglyphus arcuatus Troupeau $(1,488)$. Blattisocius tarsalis Berlese, C. arcuatus, and D. gallinae were found on traps, feathers, poultry farm nests without cages (free), and abandoned bird nests.

Key words: Acariasis; Aviculture; Dermanyssus gallinae; Ectoparasite; Megninia ginglymura 


\section{Introduction}

The laying hens, free and wild birds may carry pathogenic organisms and ectoparasites to the farms linked to commercial aviculture. Although the Ministério da Agricultura, Pecuária e Abastecimento (MAPA) try to control the presence of birds and other animals on poultry farms, is unlikely to be able to eradicate wild birds from nearby farms. The integral control of people and objects, flux and ectoparasites is essential for the maintenance biosecurity. The absence of these controls increases the diseases risk (BORNE; COMTE, 2003).

Dermanyssus gallinae (De Geer) (Dermanyssidae) also known as the poultry red mite (PRM), is an epidemiological and economical problem for the poultry industry worldwide. This ectoparasite is hematophagous and is responsible for egg downgrading and spotting, anaemia in birds and more reports suggest it could be a etiologic agents vector of several human and animal diseases. It is the most important ectoparasite affecting laying hens (CHAUVE, 1998). Megninia ginglymura (Mégnin) (Analgidae) is an ectoparasite found in bird feathers (FLECHTMANN, 1985). Their saliva causes allergic reactions, stress and the itching leads to the development of petechiae hemorrhagic, vesicles and the crust formation on the site providing secondary bacterial infections and pyorderma(TUCCI et al., 2005). Studies with the aim of finding a natural predator to D. gallinae, in their natural habitat, were developed by Lesna et al. (2009), in samples by nests abandoned Sturnus vulgaris (Linnaeus) (Sturnidae) in the Netherlands.

Currently, studies on population dynamics and efficient techniques for the control of hematophagous mites are scarce in Brazil. Until now, nothing is known about the mite fauna associated to D. gallinae and commercial laying birds in Rio Grande do Sul. Due to the importance of this activity to the economy of Taquari Valley and state, it is necessary to know the associated mites, their frequency and damages caused by them. Moreover, it is essential to know what laying hens and wild birds are carriers of the pest mites for poultry houses. In this context also arises the need to improve certain methods of control of ectoparasites in the productive system of commercial laying eggs, because the market is demanding new processes and methodologies that focus on product quality, environmental, worker health and rural animal welfare. This study investigates the mite fauna associated to bird's nests abandoned and commercial laying hens of poultry egg-laying business.

\section{Materials and Methods}

This study was conducted in birds' nests abandoned and egg-laying poultry commercial between December 2010 to July 2011 in Lajeado and Teutônia Counties, in Taquari Valley, Rio Grande do Sul, Brazil. The abandoned nests were stored in plastic sacks, kept refrigerated and sent to the Acarology Laboratory, University Center UNIVATES to realize the extraction of mites. Mites found were collected with fine-tipped paintbrush and mounted with Hoyer's medium on microscopic slides (WALTER-KRANTZ, 2009).

In Lajeado were collected a Hylocharis sp. (hummingbird) nest; nearby of UNIVATES University Center, a Troglodytes musculus (Naumann) (southern house wren) and hummingbirds nests and in Teutônia two Turdus rufiventris Vieillot nests (rufous-bellied thrush). To identify these birds was used Belton (1994) and the birds were monitored and identified before to abandon the nest. Four poultry houses were sampled in Teutônia in wooden sheds, being what in two, the birds were kept metal cage battery (Cage) and the other two, the birds were raised free, on wooden pallet with nests and roosts disposition, with feeders tubular and drinkers pendulous and with free access to farm courtyard, where they took the sun, flying, wings beating, running, pecked and revolved along the ground (Free range). In cage system, to make samples were prepared cardboard traps with $100 \mathrm{~mm}$ width $\times 70 \mathrm{~mm}$ length $\times 3 \mathrm{~mm}$ height, as suggested by Cunha et al. (2009). The cardboard traps were distributed near the superior vertex, sides and in front of the cages selected randomly; in free range system of traps were placed on roosts, nests, columns and walls, following the method used by Lesna et al. (2009). The traps were changed every 15 days and always fixed at the same point. These traps, without acaricides, usually try to imitate the hiding places searched by D. gallinae, facilitating their capture (CHIRICO; TAUSAN, 2002). 
In each poultry house were exposed five traps, totaling 20 traps every 15 days following by Lesna et al. (2009). After the exposure period, traps were collected and placed in plastic bag, identified and kept under refrigeration in laboratory until the realization of screening material. Five nests were sampled in Free range system, where was collected a portion of nest substrate, placed on identified plastic bag and moved to laboratory.

To identify the mites present in the feathers were removed three feathers from nine birds to each poultry house, totalizing 108 feathers/month/poultry house. Hughes (1976) and Flechtmann (1985) were used to identify the species. Voucher specimens were deposited in mites reference collection of the Museum of Natural Sciences - University Center UNIVATES (ZAUMCN), Lajeado, Rio Grande do Sul.

\section{Results}

A total of 11,757 mites belonging to 21 families and 31 species were found. Most, about $99 \%$ of specimens were collected in poultry house, in Teutônia. The Cheyletidae showed increased number of species, with four species and Blattisocidae, with three species. Acaridae, Glycyphagidae, Laelapidae and Phytoseiidae had two species. Dermanyssidae show higher abundance, with 5,689 specimens, followed by Analgidae with 2,175 and Chortoglyphidae with 1,488. Pyroglyphus sp. was collected only in feathers, while $M$. gynglimura was found in feathers, traps and poultry farm nests in free range system. Blattisocius tarsalis (Berlese), Chortoglyphus arcuatus (Troupeau) and D. gallinae, they are also found in the traps, on feathers, poultry farm nests in both system and also in abandoned bird's nest.

\section{Blattisocius keegani (Fox), Blattisocius} dentriticus (Berlese), Cheyletus eruditus (Schrank), Cheyletus malaccensis (Oudemans), Cheletomorpha lepidopterorum (Shaw), Ctenoglyphus sp., Lepidoglyphus destructor and Typhlodromus transvaalensis (Nesbitt) were present in traps and poultry farm nests free range system. Tyrophagus putrescentiae (Schrank) and Uropodidae were found in bird's nest abandoned, nests of poultry farm free range and also on the feathers. Oribatids mites were collected from abandoned bird's nest, in the traps and nests of poultry in free range system (Figure 1).

FIGURE 1: Mites found in feathers, traps, hen's nest and abandoned bird's nest betweenDecember 2010 to July 2011 in Lajeado and Teutônia Counties, Rio Grande do Sul, Brazil.

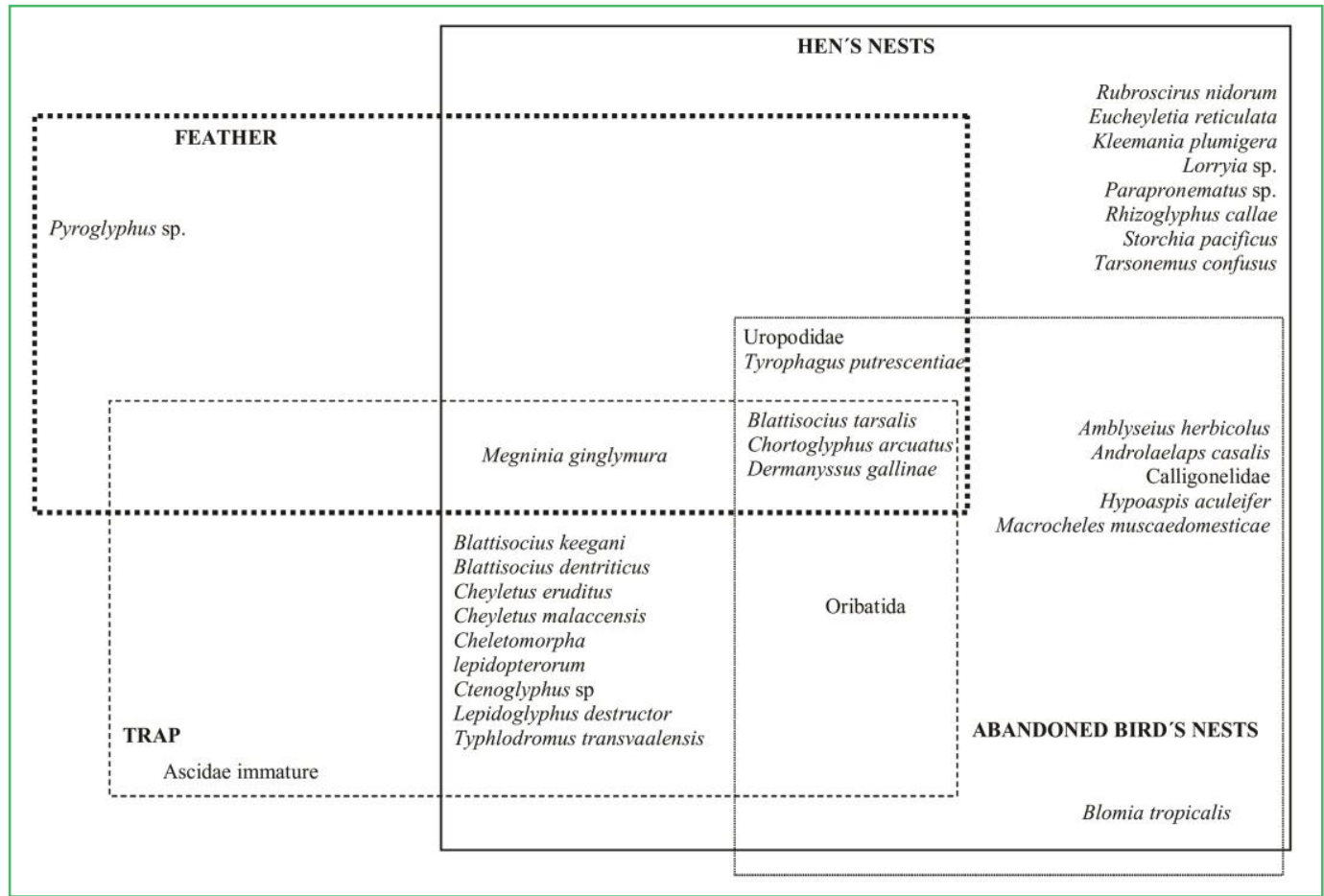


In the nests were found exclusively Rubroscirus nidorum Ferla; Rocha, Eucheyletia reticulata (Cunliffe), Kleemania plumigera (Oudemans), Lorryia sp., Parapronematus sp., Rhizoglyphus callae (Oudemans), Storchia pacificus (Summers) and Tarsonemus confusus (Ewing). In both, poultry houses and abandoned bird's nest were collected Amblyseius herbicolus (Chant), Androlaelaps casalis, a species of Calligonelidae, Hypoaspis aculeifer (Canestrini) and Macrocheles muscaedomesticae (Scopoli). Blomia tropicalis (VAN BRONSWIJCK et al., 1973) was collected exclusively in abandoned bird's nest (Figure 2) and an Ascidae immature was found only in cardboard trap.

The mite species and the environments where found collected are presented below, along with the municipality, month and year of collection. Specimens' numbers are showed in parentheses.

\section{Suborder Mesostigmata}

Blattisocidae Garman, 1948

Blattisocius dentriticus (Berlese, 1918)

Lasioseius (L.) dentriticus Berlese, 1918: 7-16.

Locality of the specimens examined: Brazil, Rio Grande do Sul, TEUTÔNIA: Trap: Cage: XII-2010
(10). Hen's nest: III-2011(1), IV-2011(1), V-2011(4), VI-2011(1).

Comments: Blattisocius dentriticus feeds eggs of other arthropods and T. putrescentiae (FENILLI; FLECHTMANN, 1990). Species associated with imported food in the United States (HUGHES, 1976). Blattisocius dentriticus is a predator that competes with Cheyletus eruditus (COLLINS, 2012).

Blattisocius keegani (Fox, 1947)

Melichares (B.) keegani Fox, 1947: 598-603

Locality of the specimens examined: Brazil, Rio Grande do Sul, TEUTÔNIA: Trap: Cage: I-2011(2). Hen's nest: III-2011(1), IV-2011(1), V-2011(3).

Comments: Blattisocius keegani control beetles in stored products. There are evidences that this species feeds on lepidopteran eggs and present potential for biological control of fly larvae in orange (THOMAS et al., 2011).

Blattisocius tarsalis (Berlese, 1918)

Melichares (B.) tarsalis Berlese, 1918.

Locality of the specimens examined: Brazil, Rio Grande do Sul, TEUTÔNIA: Trap: Cage: I-2011(2). Hen's nest: II-2011(3), III-2011(3), IV-2011(1), V-2011(4). Feather:

FIGURE 2: Mites found in abandoned bird's nest between December 2010 to July 2011 in Lajeado and Teutônia Counties, Rio Grande do Sul, Brazil.

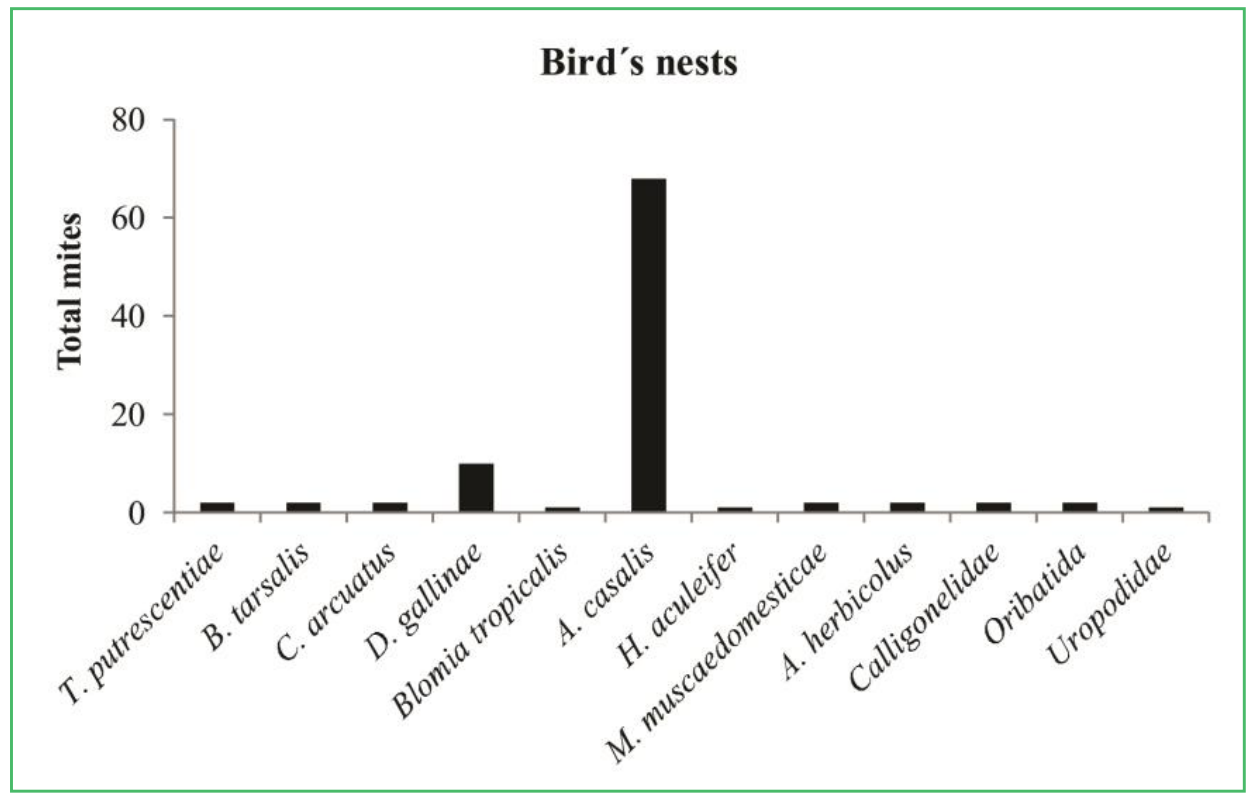


Cage: VII-2011(1); Free range: V-2011(2). LAJEADO: Abandoned bird's nest: (2).

Comments: Blattisocius tarsalis has been used in biological control in flour mills, because it acts effectively on the flour moth (Ephestia kuehniella) (Zeller) (Lepidoptera: Pyralidae) (NIELSEN, 1998). This species is known as predatory larvae of insects in stored grain (TREAT, 1969), beyond what is shown as an active predator of eggs of Acarus siro L. in stored products (THIND; FORD, 2006).

\section{Ameroseiidae Evans, 1963}

Kleemania plumigera (Oudemans, 1930)

Zercoseius gracei Hughes, 1948:168.

Locality of the specimens examined: Brazil, Rio Grande do Sul, TEUTÔNIA: Hen's nest: III-2011(2), V-2011(11), VI-2011(2).

Comments: Kleemania plumigera may occur in hay warehouses in debris and crumbling walls in new buildings, but in this environment, usually disappears once the area becomes drier. It has also been found in reused litter (HUGHES, 1976). In studies between 2000 and 2006, in Greece, met Kleemania plumigera on farms and in environments of agricultural cooperatives (PALYVOS et al., 2008).

Dermanyssidae Kolenati, 1859

Dermanyssus gallinae (De Geer, 1778)

Acarus gallinae De Geer, 1778.

Locality of the specimens examined: Brazil, Rio Grande do Sul, TEUTÔNIA: Trap: Cage: XII-2010(1746), I-2011(60), II-2011(13), IV-2011(4), V-2011(7); Free range: I-2011(12), III-2011(30), IV-2011(8), V-2011(552), VI-2011(3011), VII-2011(208). Hen's nest: I-2011(14), VI-2011(3). Feather: Cage: V-2011(1), VI-2011(2), VII-2011(7); Free range: VI-2011(1). LAJEADO: Abandoned bird's nest: (10).

Comments: Dermanyssus gallinae is a health and economic problem in commercial laying poultry. Injuries during its blood meal can be identified on chest and legs of birds (TUCCI; GUIMARÃES, 1998). Causes stress, theft, due to hematophagous activity, anemia, and decrease in egg production and may also be a vector of pathogenic microorganisms (BACK, 2004).

Laelapidae Berlese, 1892

Androlaelaps casalis (Berlese, 1887)

Iphis casalis Berlese, 1887:8

Locality of the specimens examined: Brazil, Rio Grande do Sul, TEUTÔNIA: Hen's nest: V-2011(8), VII2011(1). LAJEADO: Abandoned bird's nest: (68).

Comments: Androlaelaps casalis is a generalist mite predator of T. putrescentiae, Glycyphagus domesticus (De Geer), Blattisocius keegani (Hughes) and immature of D. gallinae (HUGHES, 1976; LESNA et al., 2009).

Hypoaspis aculeifer (Canestrini, 1884)

Laelaps aculeifer Canestrini, 1884:705

Locality of the specimens examined: Brazil, Rio Grande do Sul, TEUTÔNIA: Hen's nest: II-2011(12), V-2011(2), VI-2011(1). LAJEADO: Abandoned bird's nest: (1).

Comments: Hypoaspis aculeifer feeds on other mites, small insects and nematodes. Their larvae don't feed and adult forms may eat their own eggs. It feeds also T. putrescentiae (ZHANG, 1963) and immature of $D$. gallinae (LESNA et al. 2009).

Macrochelidae Vitzhum, 1930

Macrocheles muscaedomesticae (Scopoli, 1772)

Acarus muscaedomesticae Scopoli, 1772:1-128.

Locality of the specimens examined: Brazil, Rio Grande do Sul, TEUTÔNIA: Hen's nest: II-2011(49), IV-2011(2). LAJEADO: Abandoned bird's nest: (2).

Comments: Macrocheles muscaedomesticae is a predator (LESNA et al., 2009) of house fly and related species. It is found in manure, including poultry manure, habitat conducive to the development of flies. Larvae and adults feed on the eggs of flies. It is common to find female $M$. muscaedomesticae in stored food or in any other place where have flies (ZHANG, 1963).

Phytoseiidae Berlese, 1913 


\section{Amblyseiinae}

Amblyseius herbicolus (Chant, 1959)

Typhlodromus (Amblyseius) herbicolus Chant, 1959:84.

Locality of the specimens examined: Brazil, Rio Grande do Sul, TEUTÔNIA: Hen's nest: V-2011(1). LAJEADO: Abandoned bird's nest: (2).

Comments: Amblyseius herbicolus is predator of the Tegolophus australis (Hely) (Eriophyidae) and Panonychus citri (McGregor) in orange plants (BEATTIE et al., 1991). Species commonly found in trees and vegetation near agroecosystems (REIS; ZACARIAS, 2007; SPONGOSKI et al., 2005). In Rio Grande do Sul was collected in yerba mate culture, grapevine and native vegetation (FERLA; MORAES 2002; FERLA et al., 2005; 2011).

\section{Typhlodrominae}

Typhlodromus transvaalensis (Nesbitt, 1951)

Kampimodromus transvaalensis Nesbitt, 1951:55.

Locality of the specimens examined: Brazil, Rio Grande do Sul, TEUTÔNIA: Trap: Cage: I-2011(1), V-2011(2); Free range: III-2011(1). Hen's nest: II-2011(1), III2011(1).

Comments: This species was collected from native vegetation and vines in the state of Rio Grande do Sul (FERLA; MORAES, 2002; FERLA et al., 2011).

Uropodidae Kramer, 1881

Locality of the specimens examined: Brazil, Rio Grande do Sul, TEUTÔNIA: Hen's nest: I-2011(2), II-2011(28), III-2011(1), IV-2011(2), V-2011(2), VI-2011(11), VII2011(1). Feather: Cage: VI-2011(1). LAJEADO: Abandoned bird's nest: (1).

Comments: They are mites that live in forests, fertile soil and manure. They feed on bread, yeast and immature stages of flies. These mites are phoretic, attach to the surface of their prey. There are studies reporting that some uropodinas are carnivores (GERSON; SMILEY, 1990).

\section{Suborder Prostigmata}

Caligonellidae Grandjean, 1944

Locality of the specimens examined: Brazil, Rio Grande do Sul, TEUTÔNIA: Hen's nest: I-2011(1), V-2011(1). LAJEADO: Abandoned bird's nest: (2).

Comments: Some species were cited feeding on eggs of spider mites (SUMMERS; SCHLINGER, 1955; DOSSE, 1967).

Cheyletidae Leach, 1815

Cheyletus eruditus (Schrank, 1781)

Eutarsus cancriformis Hessling, 1852: 255-259.

Locality of the specimens examined: Brazil, Rio Grande do Sul, TEUTÔNIA: Trap: Free range: III-2011(1), V-2011(1). Hen's nest: I-2011(12), II-2011(25), III2011(23), IV-2011(85), V-2011(40), VI-2011(37), VII2011(6).

Comments: Cheyletus eruditus has been observed feeding on young forms of D. gallinae (MAURER; HERTZBERG, 2001). Cheyletus eruditus practice cannibalism in the absence of food, or when kept with food with low nutritional value. There are reports of stored grains containing only $C$. eruditus without any prey (CEBOLLA et al., 2009).

Cheyletus malaccensis (Oudemans, 1903)

Cheyletus munroi Hughes, 1948:168.

Locality of the specimens examined: Brazil, Rio Grande do Sul, TEUTÔNIA: Trap: Cage: VI-2011(1); Free range: III-2011(1). Hen's nest: I-2011(40), II-2011(50), III-2011(44), IV-2011(90), V-2011(164), VI-2011(368), VII-2011(40).

Comments: Cheyletus malaccensis is related to biological control of prey and has proved very effective in controlling Lepidoglyphus destructor and T. putrescentiae. This mite also practiced cannibalism in the absence of food, or when kept with food with low nutritional value (CEBOLLA et al., 2009).

Cheletomorpha lepidopterorum (Shaw, 1794)

Acarus lepidopterorum Shaw, 1794:187.

Locality of the specimens examined: Brazil, Rio Grande do Sul, TEUTÔNIA: Trap: Free range: VII-2011(4). 
Hen's nest: I-2011(1), IV-2011(1), V-2011(2), VI2011(4).

Comments: Cheletomorpha lepidopterorum is often found in association with other mites, and has been found in association with C. eruditus on oat in bulk, however, C. eruditus moves faster than C. lepitopterorum and then it can feed (HUGHES, 1976).

Eucheyletia reticulata Cunliffe, 1962

Eucheyletia reticulata Cunliffe, 1962: 200-201.

Locality of the specimens examined: Brazil, Rio Grande do Sul, TEUTÔNIA: Hen's nest: V-2011(1), VI-2011(26).

Comments: This is the first citation of this species in the state of Rio Grande do Sul.

Cunaxidae Thor, 1902

Rubroscirus nidorum Ferla; Rocha, 2012

Locality of the specimens examined: Brazil, Rio Grande do Sul, TEUTÔNIA: Hen's nest: I-2011(1), III-2011(7), V-2011(3), VI-2011(5).

Comments: Cunaxidae are fast runners and appear feeding on various small arthropods that occur in different cultures (GERSON; SMILEY, 1990). The cunaxids are cited by Gerson et al. (2003) as predators of mites tenuipalpids, eriophyids and especially nematodes.

Iolinidae Pritchard, 1956

Parapronematus sp.

Locality of the specimens examined: Brazil, Rio Grande do Sul, TEUTÔNIA: Hen's nest: III-2011(1), IV2011(5), VI-2011(1).

Comments: It is a predatory mite found in fields of rubber, in the State of Mato Grosso, Brazil, in a study conducted between 1998 and 2000 (FERLA; MORAES, 2008).

Stigmaeidae Oudemans, 1931

Storchia pacificus (Summers, 1964) Apostigmaeus pacificus Summers, 1964: 184-186. Locality of the specimens examined: Brazil, Rio Grande do Sul, TEUTÔNIA: Hen's nest: III-2011(1), V-2011(2), VI-2011(20), VII-2011(3).
Comments: Species described from specimens from Indonesia and the Philippines intercepted in Hawaii of Manihot esculenta Crantz (cassava, manioc or cassava) and Oryza sativa L. (rice) (SUMMERS, 1964).

Tarsonemidae Kramer, 1877

Tarsonemus confusus Ewing, 1939

Tarsonemus confusus Ewing, 1939:1-63.

Locality of the specimens examined: Brazil, Rio Grande do Sul, TEUTÔNIA: Hen's nest: IV-2011(6).

Comments: Tarsonemus confusus is a species commonly found in plants, soil, dust in houses and bird nests. Fungivorous and also known as a pest of some ornamental plants in greenhouses in Europe and tomatoes of North Africa (ZHANG, 1963).

Tydeidae Kramer, 1877

Lorryia sp.

Locality of the specimens examined: Brazil, Rio Grande do Sul, TEUTÔNIA: Hen's nest: IV-2011(7), V-2011(4), VI-2011(3).

\section{Suborder Astigmata}

Acaridae Ewing \& Nesbitt, 1954

Rhizoglyphus callae (Oudemans, 1924)

Rhizoglyphus lucasii Hughes, 1948: 168.

Locality of the specimens examined: Brazil, Rio Grande do Sul, TEUTÔNIA: Hen's nest: II-2011(7), V-2011(3).

Comments: Rhizoglyphus callae is found in tulip bulbs, which attacks the leaves humid and has been found in deposits grease from pigs (HUGHES, 1976). They are pests of many crops and ornamental plants (DIAZ et al., 2000).

Tyrophagus putrescentiae (Schrank, 1781)

Acarus putrescentiae Schrank, 1781: 552.

Locality of the specimens examined: Brazil, Rio Grande do Sul, TEUTÔNIA: Hen's nest: I-2011(2), II-2011(12), III-2011(48), IV-2011(4), V-2011(73), VI2011(419), VII-2011(209). Feather: Cage: IV-2011(1), VII-2011(6); Free range: VI-2011(1). LAJEADO:

Abandoned bird's nest: (2). 
Comments: Tyrophagus putrescentiae is commonly associated with stored foods with high grease content and protein such as flour, wheat, soy, cheese, rye bread, milk powder and various seeds. High infestations cause deterioration in the quality and hygiene of the product and can accelerate deterioration (DUEK et al., 2001).

Analgidae Trouessart, 1915

Megninia ginglymura (Mégnin, 1877)

Megninia ginglymura Canestrini \& Kramer, 1899:1-193.

Locality of the specimens examined: Brazil, Rio Grande do Sul, TEUTÔNIA: Trap: Cage: XII2010(30), V-2011(1). Free range: V-2011(1). Hen's nest: I-2011(2), II-2011(2), III-2011(1), V-2011(4), VI-2011(3), VII-2011(1). Feather: Cage: I-2011(108), II-2011(24), III-2011(97), IV-2011(402), V-2011(284), VI-2011(253), VII-2011(91); Free range: I-2011(14), II-2011(295), III-2011(246), IV-2011(240), V-2011(40), VI-2011(13), VII-2011(23).

Comments: Megninia ginglymura feeds the feathers of birds infested. The mite's saliva causes an allergic reaction, stress, and intense itching, which leads to the formation of crusts, facilitating secondary bacterial infections and pyoderma. The itching may cause petechiae and hemorrhagic blisters on the skin of the bird parasitized (TUCCI et al., 2005).

Chortoglyphidae Berlese, 1897

Chortoglyphus arcuatus (Troupeau, 1879)

Tyroglyphus arcuatus Troupeau, 1879.

Locality of the specimens examined: Brazil, Rio Grande do Sul, TEUTÔNIA: Trap: Cage: V-2011(1), VI-2011(1). Hen's nest: I-2011(45), II-2011(49), III2011(153), IV-2011(272), V-2011(271), VI-2011(600), VII-2011(85). Feather: Cage: VII-2011(1); Free range: VII-2011(8). LAJEADO: Abandoned bird's nest: (2).

Comments: Chortoglyphus arcuatus is a mite identified in dust samples mattress, is commonly found in rural areas of Central Europe, being responsible for allergies in farmers (SCHULZ et al., 2004).

Glycyphagidae Cunliffe, 1958

Blomia tropicalis Van Bronswijck, Cock \& Oshima, 1973
Blomia tropicalis Van Bronswijck, Cock \& Oshima 1973: 477-489.

Locality of the specimens examined: Brazil, Rio Grande do Sul, LAJEADO: Abandoned bird's nest: (1).

Comments: Blomia tropicalis is associated with occupational asthma in farmers and grain handlers. It occurs in tropical and subtropical regions in dust. In the United States, is very common in dust from mattresses and carpets of houses (ARRUDA; CHAPMAN, 1992). In Rio Grande do Sul was found in residences (FERLA; NEUMANN, 2004).

\section{Ctenoglyphus sp.}

Locality of the specimens examined: Brazil, Rio Grande do Sul, TEUTÔNIA: Trap: Free range: V-2011(1). Hen's nest: II-2011(1).

Comments: Ctenoglyphus plumiger occurs in barns, wheat, oats and barley, grass seed, and sometimes appears in large populations, in the hay. It has been found in fish meal and honeycombs (HUGHES, 1976).

Lepidoglyphus destructor (Schrank, 1781)

Acarus destructor Schrank, 1781:552.

Locality of the specimens examined: Brazil, Rio Grande do Sul. TEUTÔNIA: Trap: Cage: VII-2011(1). Hen's nest: I-2011(3), IV-2011(3), V-2011(18), VI-2011(123), VII-2011(47).

Comments: Lepidoglyphus destructor occurs worldwide in stored grains and also in animal feed. In periods of high humidity, especially in hay stored, there may be rampant infestation, reaching 50,000 mites per $\mathrm{kg}$ of hay. In addition to economic losses, the mite is a public health problem, since it may be responsible for cases of occupational diseases such as asthma among rural workers (KNÜLLE, 1991).

Pyroglyphidae Cunliffe, 1958

Pyroglyphus sp.

Locality of the specimens examined: Brazil, Rio Grande do Sul, TEUTÔNIA: Feather: Free range: VI-2011(1).

Comments: Pyroglyphus sp. is found in the nests of rodents and birds (HUGHES, 1976). 


\section{Suborder Oribatida}

Locality of the specimens examined: Brazil, Rio Grande do Sul, TEUTÔNIA: Trap: Cage: III-2011(1); Free range: V-2011(1). Hen's nest: II-2011(11), III-2011(1), VI-2011(1). LAJEADO: Abandoned bird's nest: (2).

Comments: Oribatids mites are common in the soil. They feed on fungi and fallen plants, are important in decomposition and soil formation. There are few species that live in the aerial parts of plants, but still has economic importance because they are known as plant pests (ZHANG, 1963).

\section{Discussion}

The biological control of mite pests by natural predators can help reduce high infestations, preventing that these ectoparasites becoming a health and economic problem. Lesna et al. (2009) commented that, as the eggs are produced for human consumption must meet stringent food safety standards, in other words, the eggs must be free of debris and for the use of acaricide products, there must be a rapid degradation of the compounds used for components which are not harmful. Also commented that the products cannot be harmful to health or well being of the squad. In spite of using chemical sprays directly on the birds, the synthetic acaricides currently used has limitations as well as unfeasibility eradication and residues presence in eggs, because the red mite spends most of the time housed in their hiding places, places where spraying will hardly reach (LESNA et al., 2009). These authors in Dutch provinces, found in birds' nests D. gallinae, A. casalis, C. eruditus and L. destructor. These specimens were also found in Teutônia poultry houses and in abandoned nests collected in Taquari Valley, Rio Grande do Sul, Brazil.

Our results highlighted on commercial hen's nests a high predator population belonging to Cheyletidae and Cunaxidae families if compared with Lesna et al. (2009). Eucheyletia reticulata is the first citation of this species in the state of Rio Grande do Sul and, according to Cebolla et al. (2009), Cheyletus malaccensis is reported like a biological agent controlling effectively L. destructor and T. putrescentiae. In this work it may be feeding of Tyrophagus putrescentiae in nests or Dermanyssus gallinae. Rubroscirus nidorum is the first species of the genus to be described for commercial laying hens.

This study showed that specimens collected in abandoned nests of birds can also be seen in poultry farm for commercial egg laying excepting specimens of Pyroglyphus sp. on feathers which was found in specific places. Thus, it is concluded that wild birds are often similar mitefauna of the natural environment for commercial poultry farms. The access restriction to farm of wild birds could reduce limit the entry of mite disseminators of diseases, causing economic losses to farmers and the poultry industry.

\section{References}

ARRUDA, L. K.; CHAPMAN, M. D. A review of recent immunochemical sutdies of Blomia tropicalis and Euroglyphus maynei allergens. Experimental and Applied Acarology, Amsterdam, v. 16, p. 129-140, 1992.

BACK, A. Manual de doenças das aves. Cascavel: Coluna do Saber, 2004. 222 p.

BEATTIE, G. A. C.; ROBERTS, E. A.; VANHOFF, C. L.; FLACK, L. K. Effects of climate, natural enemies and biocides on three citrus mites in coastal New South Wales. Experimental and Applied Acarology, Amsterdam, v. 11, p. 271-295, 1991.

BELTON, W. Aves do Rio Grande do Sul: distribuição e biologia. São Leopoldo: UNISINOS, 1994. 584 p.

BORNE, P-M.; COMTE, S. Vacinas e vacinação na produção avícola. São Paulo: Porto Feliz, 2003. 140 p.

CEBOLLA, R.; PEKAR, S.; HUBERT, J. Prey range of the predatory mite Cheyletus malaccensis (Acari: Cheyletidae) and its efficacy in the control of seven stored-products pests. Biological Control, Cambridge, v. 50, p. 1-6, 2009.

CHIRICO, J.; TAUSAN, R. Traps containing acaricides for the control of Dermanyssus gallinae. Veterinary Parasitology, Amsterdam, v. 110, p. 109-116, 2002.

COLLINS, D. A. A review on the factors affecting mite growth in stored grain commodities. Experimental and Applied Acarology, Amsterdam, v. 56, p. 191-208, 2012.

CUNHA, L. M.; CUNHA, M. M.; LEITE, R. C.; SILVA, I. J.; OLIVEIRA, P. R. de. Comparação da eficiência de diferentes armadilhas usadas para captura de Dermanyssus gallinae (Acari: Dermanyssidae) (De Geer, 1978). Revista Brasileira de Parasitologia Veterinária, Jaboticabal, v. 18, n. 4, p. 59-62, 2009. DIAZ, A.; OKABE, K.; ECKENRODE, C. J.; VILLANI, M. G.; OCONNOR, B. M. Biology, ecology, and management of the bulb mites of the genus Rhizoglyphus (Acari: Acaridae). Experimental and Applied Acarology, Amsterdam, v. 24, p. 85-113, 2000. 
DOSSE, G. Schadmilben des Libanons und ihre Pradatoren. Zeitschrift für Angewandte Entomologie, Hamburg, v. 59, p. 1648, 1967.

DUEK, L.; KAUFMAN, G.; PALEVSKY, E.; BERDICEVSKY, I. Mites in fungal. Micoses, Berlin, v. 44, p. 390-394, 2001.

FENILlI, R.; FLECHTMANN, C. H. W. Ácaros do Pinheirodo-Paraná em Lajes, Santa Catarina. Anais Escola Superior de Agricultura Luiz de Queiroz, Piracicaba, v. 47, Parte 1, p. 243$250,1990$.

FERLA, N. J.; JOHANN, L.; KLOCK, C.; MAJOLO, F.; BOTTON, M. Phytoseiid mites (Acari: Phytoseiidae) from vineyards in Rio Grande do Sul State, Brasil. Zootaxa, Auckland, v. 2976, p. 15-31, 2011.

FERLA, N. J.; MARCHETTI, M. M.; SIEBERT, J. C. Acarofauna (Acari) de erva mate (Ilex paraguariensis St. Hil.: Aquifoliaceae) no Estado do Rio Grande do Sul, Brasil. Biociências, Porto Alegre, v. 13, n. 2, p. 133-142, 2005.

FERLA, N. J.; MORAES, G. J. de. Ácaros (Arachnida, Acari) da seringueira (Hevea brasiliensis Muell. Arg.) no Estado do Mato Grosso, Brasil. Revista Brasileira de Zoologia, Curitiba, v. 19, n. 3, p. 867-888, 2002.

FERLA, N. J.; MORAES, G. J. de. Flutuação populacional e sintomas de dano por ácaros (Acari) em seringueira no Estado do Mato Grosso, Brasil. Revista Árvore, Viçosa, v. 32, n. 2, p. $365-$ 376, 2008.

FERLA, N. J.; NEUMANN, F. D. Ácaros (Acari) causadores de alergias e sua importância para a saúde humana. In: SEMINÁRIO DO MERCOSUL SOBRE PEDICULOSE, ESCABIOSE E TUNGÍASE: UMA ABORDAGEM INTERDISCIPLINAR DOS SEUS PROBLEMAS E CUIDADOS, I, 2004, São Leopoldo. Anais... São Leopoldo: UNISINOS, 2004. p. 50-53.

FLECHTMANN, C. H. W. Ácaros de importância médicoveterinária. 3. ed. São Paulo: Nobel, 1985. 192 p.

GERSON, U.; SMILEY, R. L. Acarine biocontrol agents: an illustrated key and manual. London: British Library Cataloguing in Publication Data, 1990. 174 p.

GERSON, U.; SMILEY, R. L.; OCHOA, R. Mites (Acari) for pest control. Malden: Blackwell Science, 2003. 540 p.

HUGHES, A. M. The mites of stored food and houses. London: Technology Bulletin Agric. Fish. Food, n. 9, 1976. 400 p.

KNÜLLE, W. Genetic and environmental determinants of hypopus duration in the stored-product mite Lepidoglyphus destructor. Experimental and Applied Acarology, Amsterdam, v. 10, p. 231$258,1991$.

LESNA, I.; WOLFS, P.; FARAJI, F.; ROY, L.; KOMDEUR, J.; SABELIS, M. W. Candidate predators for biological control of the poultry red mite Dermanyssus gallinae. Experimental and Applied Acarology, Amsterdam, v. 48, p. 63-80, 2009.

MAURER, V.; HERTZBERG, H. Ökologische legehennenhaltung. Was tun gegen die kleinen Vampire? DGS Magazin, Stuttgart, v. 40, p. 49-52, 2001.

NIELSEN, S. The use of Blattisocius tarsalis (Acari: Ascidae) for biological control in flour mills. In: INTERNATIONAL WORKING CONFERENCE ON STORED-PRODUCT PROTECTION, 7, 1998, Beijing. Proceedings... Vol. 2. 1998. Versão eletrônica.
PALYVOS, N. E.; EMMANOUEL, N. G.; SAITANIS, C. J. Mites associated with stored products in Greece. Experimental and Applied Acarology, Amsterdam, v. 44, p. 213-226, 2008.

REIS, P. R.; ZACARIAS, M. S. Ácaros em cafeeiro. Belo Horizonte: EPAMIG, 2007. 76 p. (Boletim Técnico, n. 81)

SCHULZ, S.; FUHLENDORFF, J.; STEIDLE, J. L. M.; COLLATZ, J.; FRANZ, J-T. Identification and biosynthesis of an aggregation pheromone of the storage mite Chortoglyphus arcuatus. ChemBioChem, Basel, v. 5, p. 1500-1507, 2004.

SPONGOSKI, S.; REIS, P. R.; ZACARIAS, M. S. Acarofauna da cafeicultura de cerrado em Patrocínio, Minas Gerais. Ciência e Agrotecnologia, Lavras, v. 29, p. 9-17, 2005.

SUMMERS, F. M. Three uncommon genera of the mite family Stigmaeidae (Acarina). Proceedings of the Entomological Society of Washington, Washington, v. 66, p. 184-192, 1964.

SUMMERS, F. M.; SCHLINGER, E. I. Mites of the family Caligonellidae (Acarina). Hilgardia, Oakland, v. 23, p. 539-561, 1955.

THIND, B. B.; FORD, H. L. Laboratory studies on the use of two new arenas to evaluate the impact of the predatory mites Blattisocius tarsalis and Cheyletus eruditus on residual populations of the stored product mite Acarus siro. Experimental and Applied Acarology, Amsterdam, v. 38, p. 167-180, 2006.

THOMAS, H. Q.; ZALOM, F. G.; NICOLA, N. L. Laboratory studies of Blattisocius keegani (Fox) (Acari: Ascidae) reared on eggs of navel orangeworm: potential for biological control. Bulletin of Entomological Research, Cambridge, v. 101, p. 499504, 2011

TREAT, A. E. Association of the Mite Blattisocius tarsalis with the Moth Epizeuxis aemula. Journal of the New York Entomological Society, New York, v. 77, n. 3, p. 171-175, 1969.

TUCCI, E. C.; GUASTAli, E. A. L.; REBOUÇAS, M. M.; MENDES, M. C.; GAMA, N. M. S. Q. Infestação por Megninia spp. em criação industrial de aves produtoras de ovos para consumo. Arquivos do Instituto de Biologia, São Paulo, v. 72, n. 1, p. 121124, 2005.

TUCCI, E. C.; GUIMARÃES, J. H. Biologia de Dermanyssus gallinae (De Geer, 1778) (Acari Dermanissydae). Revista Brasileira de Parasitologia Veterinária, São Paulo, v. 7, n. 1, p. 27-30, 1998.

VAN BRONSWIJCK, J.E.M.H.; COCK, A.W.A. DE; OSHIMA, S. The genus Blomia Oudemans (Acari: Glycyphagidae) I. Description of Blomia tropicalis sp.n. from house dust in tropical and subtropical regions. Acarologia, Paris, v. 15, n. 3, p. 477-489, 1973.

WALTER, D. E.; KRANTZ, G. W. Collecting, rearing, and preparing specimens. In: KRANTZ, G. W.; WALTER, D. E. (Ed.). A manual of Acarology. 3 ed. Lubbock: Texas Tech Univesity Press, 2009. p. 83-96.

ZHANG, Z-Q. Mites of greenhouses: identification, biology and control. Cambridge: Cabi Publishing, 1963. 244 p. 